\title{
AIP wt Allele
}

National Cancer Institute

\section{Source}

National Cancer Institute. AlP wt Allele. NCI Thesaurus. Code C95462.

Human AIP wild-type allele is located in the vicinity of $11 \mathrm{q} 13.3$ and is approximately $8 \mathrm{~kb}$ in length. This allele, which encodes AH receptor-interacting protein, plays a role in the regulation of receptor signaling. Mutation of this gene is associated with various pituitary adenomas. 